\title{
Sciendo
}

RURAL SUSTAINABILITY RESEARCH 43(338), 2020

ISSN - 2256-0939

(c) Latvia University of Life Sciences and Technologies, all rights reserved http://www.Ilu.Iv/en/

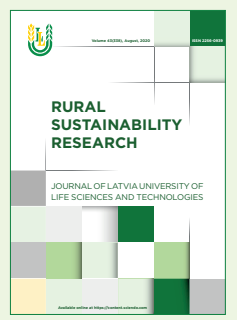

Received: 31 March 2020

Revised: 13 May 2020

Accepted: 11 June 2020

\section{Backwardness of Central and Eastern Europe as a Heritage of the Soviet Period}

\author{
*Sandris Ancans \\ Faculty of Economics and Social Development, Latvia University of \\ Life Sciences and Technologies, Jelgava, Latvia \\ ORCID ID: https://orcid.org/0000-0003-2773-3821
}

JEL code: P20

\begin{abstract}
The economy of Latvia lags behind economically developed nations approximately fourfold in terms of labour productivity in the tradable sector, which is the key constituent of a modern economy, thereby affecting future sustainable development in the entire country, including the rural areas. The economic backwardness is characteristic of the entire Central and Eastern Europe. This is the heritage of a communist regime that lasted for about half a century and the economic system termed a (centrally) planned economy or a command economy. However, such a term for the communist-period economy is not correct, as it does not represent the purpose it was created for. Accordingly, the paper aims to assess the effect of the communism period on the economic backwardness of the Central and Eastern European region of the EU. A planned economy that existed in all communist countries, with the exception of Yugoslavia, was not introduced to contribute to prosperity. It was intended for confrontation or even warfare by the communist countries under the guidance of the USSR against other countries where no communism regime existed, mostly Western world nations with their market economies. For this reason, it is not correct to term it a (centrally) planned economy or a command economy; the right term is a mobilised (war) economy. An extrapolation of a geometric progression for GDP revealed that during the half a century, Latvia as part of the USSR was forced to spend on confrontation with the West not less than EUR 17 bln. (2011 prices) or approximately one gross domestic product of 2011. The research aim of the paper is to assess the effect of the communism period on the economic backwardness of the Central and Eastern European region of the EU.
\end{abstract}

Keywords: economic backwardness, centrally planned economy, mobilised (war) economy.

\section{Introduction}

Any Central and Eastern European country (former communist countries) with the so-called command economy that existed in the communism period significantly lags behind Western European countries in terms of economic development (standard of living). In recent years, only one pronounced exception emerged - Greece - whose GDP per capita in 2018, according to Eurostat, was the fourth lowest in the EU, above that of Bulgaria, Romania and Croatia. Greece was outperformed by eight former communist countries, yet the reason for it the present paper is not going to focus on. The backwardness of the Central and Eastern European region is associated with the almost half-century long period of communism that did not facilitate economic development and, a fortiori, the economic system in most of the countries was not even intended for achieving prosperity. In 2017, according to Eurostat, labour productivity and average earnings, which strongly correlate, was approximately four-fold lower in Latvia than in advanced Western European countries. Because of significantly lower earnings, the population in Latvia and elsewhere in Eastern Europe decreases fast, moving to Western Europe in search of jobs and better life. The fast population decrease creates socio-economic etc. problems, negatively affecting sustainable development. Accordingly, the present paper focuses on explaining the main cause of

\footnotetext{
* Corresponding Author's email: sanan@1lu.lv
} 
the economic backwardness of the Central and Eastern European region, which affects future sustainable development in the region, including the rural areas, as well as aims to justify the replacement of the term command economy used in textbooks etc. with a more appropriate one - war (mobilised) economy.

Since ancient times, economic activity has been done by individuals, and the market as a system existed for the purpose of determination of value of goods (and services) and their exchange. In ancient times compared with nowadays, the assortment of goods and services the society produced and consumed was very limited, which even allowed using no money as a medium of exchange. Under the market, a good becomes relatively more expensive if there is a shortage of the good or the demand for it increases for some other reasons. The market is some kind of self-adjusting economic system that ensures goods (and services) are constantly available, and only their values (prices) change. In the author's opinion, the market could be considered a naturally, constantly and independently operating mechanism or system that can exist and perform its functions forever. However, an opposite of natural is artificial, and an artificial system has to be persistently maintained and supported because otherwise it stops operating and performing its functions.

Economics textbooks distinguish several major kinds of economies such as a traditional economy, a command economy, a market economy and a mixed economy or several economic systems such as capitalism, socialism and Marxism (communism), while some textbooks also distinguish a Soviet-style command economy, not referring to a war (mobilised) economy. To a lesser or greater extent, the market functioned under all the kinds of economies, except a command economy, and under all the economic systems, except Marxism (communism).

Throughout human history, there was (and hopefully will never be again) only one exception -a completely unnatural or artificial economic system, which is commonly known as a command economy, a (centrally) planned economy and state socialism or a socialistic economy, in most of the communist countries in the $20^{\text {th }}$ century. However, this economic system is rarely termed correctly, i.e. a war economy or a mobilised economy.

Accordingly, the research aim of the paper is to assess the effect of the communism period on the economic backwardness of the Central and Eastern European region of the EU.

The following specific research tasks were set: 1) to describe the economic system (model) of the communism period in Latvia and in other communist countries and substantiate the term mobilised (war) economy that existed in Latvia from 1945 to 1990; 2) to estimate the military expenditures of Latvia in the period 1945-1990.

\section{Methods}

The present research employed analysis and synthesis, the geometric progression method, the extrapolation method and various sources of information on the problem researched.

\section{Results and discussion}

Characteristics of a mobilised (war) economy

There are several terms used for describing the economic system that existed in the 20th century in a number of countries with a communist regime that was, in most cases, established by the USSR. The terms do not reveal the key purpose such an economic system was created for. There are relatively few references to the term war or mobilised economy. For example, Polish economist Oskar Lange referred to the economy of the Soviet Union as a "sui generis (unique) war economy" (Linden, 2007). This term, in the author's opinion, is accurate because a similar kind of war economy, presumably, never existed in human history and was not introduced in the 20th century in other communistic countries, not to mention noncommunistic countries.

In his book L'économie mobilisée: essai sur les économies de type soviétique (Mobilised Economy: an Essay on Soviet-type Economies), French economist Jacques Sapir regraded the Soviet economy "much more as a permanent war economy, in which the state directed industry and agriculture through guaranteeing demand for output. This "mobilised economy" had emerged already before the October Revolution, in 1915-16, and had, despite several political overturns and changes in form, persisted until the end of the 1980s" (Linden, 2007). This term - permanent war economy - also describes the substance of it quite well. Nevertheless, in the author's opinion, it is necessary to distinguish the mobilised economy, described by J.Sapir, that was introduced in Russia before the October revolution of 1917 from the one introduced at the end of the 1920s during the communistic regime. In Czarist Russia, its economy was mobilised in 2015, i.e. after World War I began. That mobilised economy was intended to last as long as the war continued. After the war, the economy had to return to the normal state. In contrast, the kind of economy that was introduced at the end of the 1920s was really "permanent" and stopped existing only after communism collapsed at the end of the 1980s. That economic system was established based on a justification for pre-war preparations developed by USSR Chief of the Staff of the Red Army B.Shaposhnikov, which is described 
in his military theory book entitled The Brain of the Army. According to the military justification, all the industries necessary for ensuring warfare need to be mobilised, beginning with agriculture that was much more significant in the first half of the $20^{\text {th }}$ century than today, accounting for almost half of GDP, through to manufacturing and transport. The mobilisation of agriculture or the establishment of large collective farms (collectivisation) was one of the most tragic events. The widespread explanation that the purposes of collectivisation were to change the form of land tenure in rural areas, promote agricultural industrialisation (mechanisation) and take away (forcibly, with no compensation) agricultural output in order to sell (export) it and thus develop heavy industry (Encyclopaedia Britannica, 2019) does not include one more purpose that could even be the key purpose of collectivisation - the mobilisation of this significant industry. Since the peasants did not wish to give their property (land, livestock etc.) to collective farms - a new and little understandable economic system in rural areas - an artificial famine was organised in the period 1931-1933 in which more than 10 million peasants died (in Ukraine it is called golodomor, in which approximately 7 million peasants were starved to death). Both agriculture and other industries remained mobilised up to the end of the Cold War.

In a normal or democratic country, a mobilised economy lasts for a certain period of time, approximately as long as the war continues. To mobilise the economy for a long period (permanently) (in the USSR, it was mobilised for about 60 years), a totalitarian regime is also required; the regime had some hidden elements to deceive the rest of the world - seemingly democratic elections, a parliament etc. Such a State and its economy are basically closed for the rest of the world.

One of the key peculiarities of a mobilised economy is the lack of private property. Almost everything belongs to the State (government), except for household items, which is masked under the slogan "everything belongs to the people", while in reality it does not belong to anyone because there is no private property. If everything belongs to the State, the State may utilise it as it wants or utilise it for war needs.

Money was used in the mobilised economy of the USSR, yet the money did not perform the usual functions of it. In this mobilised economy, money was less valuable than products were. In contrast, in a normal market economy money is more valuable than products, which is a stimulus for businesses to earn the money through the production and sale of goods and services, thereby contributing to the prosperity of the society as a whole. However, this disadvantage of the mobilised economy is not important under the circumstances mentioned, since the purpose of the mobilised economy is not prosperity. The function of money was partly (sometimes event fully) performed by government orders (like in the army) and penalties for not obeying the orders. For example, if food is needed for the army, urban residents etc., orders are given to the collective farms to supply the food, which are obeyed. Remuneration (money) might be given in return for the supply of food, but sometimes no remuneration is given (during the war and the post-war period). In a normal market economy, it is impossible to acquire food or any other goods for no remuneration.

In the mobilised economy, particularly during Stalin's rule, the labour concentration camp system was expanded; the camps supplied very cheap labour (about ten times cheaper) that received for their work only food, working clothing and shelter in camp barracks. The camp labour extracted minerals, constructed infrastructure objects and military industry objects. There could be found a reference that says this kind of economic system resembled modern feudalism, which the author basically agrees with, yet it has to be added that during the feudalism a small part of society could have private property and that system was not intended for long-term (permanent) war but for prosperity for this small part of society.

In the mobilised economy where "everything belonged to everyone", while in reality "nothing belonged to anyone", a large number of supervisors was needed (to avoid idleness and stealing anything useful for household needs); the supervisors controlled employees at all levels, not to mention state security officials who controlled the public beyond their working time. In a normal non-totalitarian society, with private property, such supervisors who do nothing productive in the economy and lower overall labour productivity are not needed.

Since a mobilised economy does not lead to prosperity and military expenditures are inappropriately large, there is a need to hide or falsify some part of statistical data. As pointed out in the proceedings of a conference held by the Ministry of Justice on 13 December 2013, statistics in the Soviet Union were of two kinds - one for publication and glorification of economic achievements, the other was secret; only top government officials were familiarised with the undisclosed statistics, who tried to understand the real situation in the economy (Latvijas rūpniecība pirms..., 2015).

The most important economic indicator is gross domestic product. As noted in the conference proceedings, this indicator was not used in the Soviet Union, under the pretext that it allegedly contained 


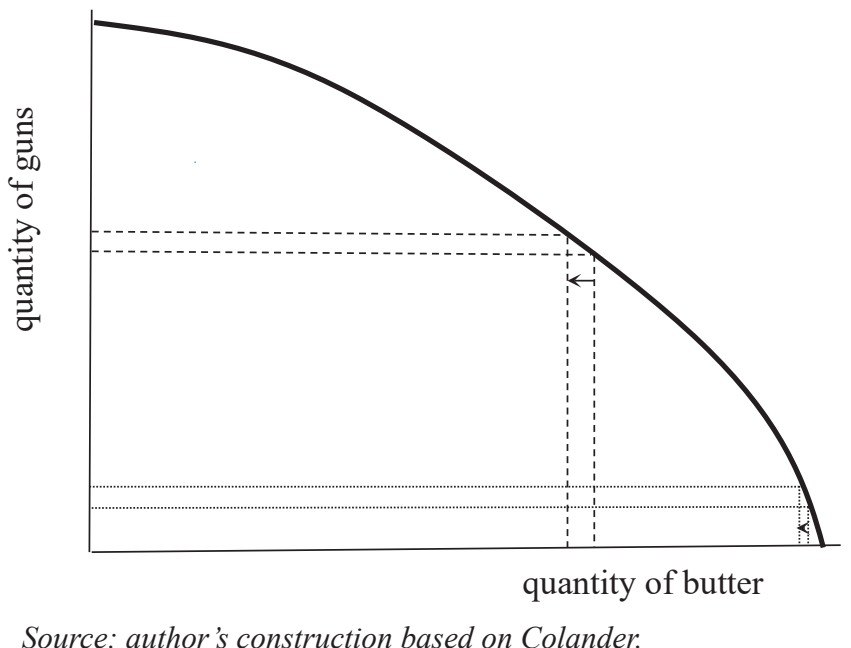

Figure 1. Production possibility frontier for "guns and butter" or the guns-and-butter curve.

some double-counted economic activities. The USSR statistical office began calculating GDP on a national scale only in 1988, terming this indicator gross national product. In Latvia, this indicator appeared only in 1990 in a statistical yearbook that disclosed some data for 1989 (Latvijas rūpniecība pirms..., 2015).

It was easy to hide statistics in the mobilised economy, which allowed developing and maintaining a disproportionally large military industry and army that lowered prosperity because they did not contribute to the prosperity, only lowered it according to the guns-and-butter curve.

As shown in Figure 1, the higher the proportion of "guns" (military expenditures), the more significant decrease in the output of "butter" (goods and services for economic prosperity), i.e. the same percentagepoint increase leads to a relatively small decrease in economic prosperity in one situation (at relatively low military expenditures as a percentage of GDP) (short arrow) or a relatively significant decrease in economic prosperity in the second situation (at relatively high military expenditures as a percentage of GDP) (long arrow). This is due to the conceived production possibility frontier - the opportunity cost of additional guns produced (in terms of butter) increases or it is an increasing marginal cost of producing guns.

As pointed out in the conference proceedings, military industry expenditures (group A) in the manufacturing output plan equalled $55.4 \%$. In the 1980 s, according to disclosed data, the output of military manufacturing products represented 20-25\% of GDP, consuming incredibly large economic resources. Three quarters of scientific research (in terms of money) were done for military purposes (Latvijas rūpniecība pirms..., 2015).

Total USSR military expenditures in the period from the end of World War II to the collapse of communism (i.e. during the Cold War) are still a secret, yet the expenditures could be estimated at 20$30 \%$ of GDP (Slikov, 2001), which is comparable to US military expenditures during World War II (about $30 \%$ of GDP) (Tassava, 2008).

Among communist countries, an opposite of the mobilised economy that existed in the USSR and partly in Eastern European countries was the economic system of Yugoslavia. The terms used to describe this economic system were as follows: market socialism and a mixed economy. In Yugoslavia, its economy was not mobilised - which was demanded by USSR dictator Stalin from the leader of this country, J.B.Tito, and it was one of the reasons why J.B.Tito turned away from the USSR dictator. Along with large state-owned factories (enterprises), small businesses existed as well. Yugoslavia was an open country and economy, even though its Communist Party was the leading political party. The standard of living was significantly higher in Yugoslavia than the USSR. Before communism collapsed in the entire Yugoslavia, GDP per capita (at 2011 prices, based on purchasing power parities (PPPs) and the Balassa-Samuelson effect) in this country reached the highest level in 1986, at USD 12484, while in Slovenia (part of Yugoslavia) it was USD 19308; for comparison, in 1989 in the USSR it was USD 15288 (Maddison Project Database, 2018). Even though GDP per capita was higher in the USSR than in Yugoslavia, it did not indicate that the standard of living in the USSR was higher. On the contrary, in the mobilised economy of the USSR, military expenditures as a share of GDP were certainly higher (approximately $30 \%$ of GDP), whereas in Yugoslavia such expenditures, a priori, were relatively lower (the author did not succeed in finding relevant data), which allowed reaching a higher standard of living even at lower GDP per capita. 


\section{Estimates of military expenditures for Latvia}

It is difficult to compare data on the mobilised economy of the USSR with those for a normal economy; therefore, in the author's opinion, the available data give only some insight into the problem concerned. The GDP of the USSR rose from USD 4113 to 14820 in the period 1946-1990, i.e. 3.6fold. For comparison, in the USA its GDP increased from USD 14471 to 36982 , i.e. 2.6-fold. In 1940, the standard of living in the USA was approximately 3.5fold higher than that in the USSR. According to the data, the standard of living in the USSR in 1990 was approximately as high as that in the USA after World War II, i.e. about before half a century (Maddison Project Database, 2018).

The data on Latvia in the mentioned database are not available, yet before 1940 the standard of living in Latvia was considerably higher than that in the USSR. In 1925-1934, the average GDP per capita measured in international dollars or Geary-Khamis dollars (GK\$) in Latvia was GK\$ 221 or $44 \%$ of that in the wealthiest nation in Europe, the UK with GK\$ 502 and $45 \%$ of that in Switzerland with GK\$ 493. In the same period, the standard of living was only $1 \%$ higher in Norway (GK\$224) than in Latvia, while in Finland it was $15 \%$ lower (GK\$ 193) than that in Latvia (Smulders, 1990). If Latvia were not part of the USSR with its mobilised economy, Latvia would have now the same average standard of living as that in the West, for example, in Finland.

Following the collapse of the USSR, output in Latvia drastically decreased; according to the data, the decrease reached 51\% (World Bank, 2002). In the author's opinion, this crisis affected the military industry the most, yet the output of some other industries considerably contracted because economic ties with Russia and other republics of the former USSR were cut as well as because of other reasons (e.g. hyperinflation in 1992), while new economic ties with the West and other world countries were not established fast enough.

The GDP per capita, measured in PPPs, that Latvia had before the collapse of the USSR was reached in 2001 (Rutkovska, 2011). The relatively fast increase in GDP per capita after the drastic decrease in output was due to a decrease in population after the collapse of the USSR, as many immigrants (civil occupants or colonists) (Riekstins, 2015), mostly from Russia, lost their jobs in the military industry and other industries and returned to their now independent countries. According to the Central Statistical Bureau (CSB), the number of residents in Latvia decreased from $2.67 \mathrm{mln}$. in 1990 to $2.35 \mathrm{mln}$. in 2001 or by $12 \%$.

According to the CSB data, the GDP of Latvia in 2001 (at current prices) was EUR 7.46 bln. The author is going to use this figure to estimate the military expenditures of Latvia (as part of the USSR mobilised economy) by extrapolating the GDP to the period from 1945 (end of World War II) to 1990 (collapse of the USSR).

Extrapolating GDP, the change in population in Latvia has to be taken into account. At the end of World War II, Latvia was inhabited by approximately $1.55 \mathrm{mln}$. residents (about an $0.5 \mathrm{mln}$. decrease due to the war). During the next years and decades, immigration into Latvia, mostly from Russia, was promoted; the immigrants were employed mostly in the manufacturing industry, including the military industry. This process was motivated politically but not economically (after World War I, Latvia was independent and achieved a considerably higher standard of living than it was in Russia, while the "main enemy" of communism was wealthy individuals. The "enemy" of the new occupation regime of communist Russia in Latvia was most of the Latvian population who were considerably wealthier than the population of Russia). In order for the Latvian people to never regain independence and even never seek to achieve it and, most importantly, never be wealthier than the population of Russia, the communist regime in Moscow decided to massively colonise Latvia (and Estonia where the standard of living was about the same as in Latvia; the colonisation was not carried out in Lithuania because the standard of living there before World War II was lower than in the other Baltic countries). The communist regime created a large and unnecessary manufacturing industry (including military industry) for which there were no domestic inputs, i.e. contrary to the principles of geographical economics - no workforce, no electric power, no raw materials, no intermediate goods -, as well as no sales market - the market (for about $90 \%$ output) was mostly in Russia, thereby incurring unnecessary transport cost. Creating and maintaining this economically unnecessary manufacturing industry resulted in wasting billions of euros (at current prices) (author's estimate). In the result of politically motivated immigration into Latvia, mostly from Russia, the number of residents in Latvia increased from $1.55 \mathrm{mln}$. in 1946 to $2.67 \mathrm{mln}$. in 1990. During this period, net immigration reached $0.94 \mathrm{mln}$. In the author's opinion, it was planned to bring in $1.5 \mathrm{mln}$. colonists, which was comparable to the number of residents living in Latvia after World War II. It was intended to reduce the proportion of the native population to about 40 $45 \%$, which would be sufficient to ensure Latvia never regains independence from Russia. The economically unreasonable manufacturing industry was created and the politically motivated immigration occurred relatively gradually. The population of Latvia reached 
$1.9 \mathrm{mln}$. in 1950, $2.1 \mathrm{mln}$. in 1960, $2.35 \mathrm{mln}$. in 1970 , $2.5 \mathrm{mln}$. in 1980 and almost $2.7 \mathrm{mln}$. in 1990. In 2001, the population of Latvia was $2.35 \mathrm{mln}$. and the GDP of Latvia equalled EUR $7.46 \mathrm{mln}$., putting GDP per capita at current prices at EUR 3174 (author's calculations).

According to the Maddison project database data, GDP per capita in the USSR rose 3.6-fold from USD 4113 to 14820 in the period 1945-1990, which allows calculating the average GDP growth rate (\%) by the following geometric progression equation:

$$
r^{n-1}=l / a
$$

Where

$\mathrm{r}$ - common ratio;

$\mathrm{n}$ - number of terms; $\mathrm{n}=45$ (years);

1 - last term; $1=14820$ (USD);

$\mathrm{a}$ - first term; $\mathrm{a}=4113$ (USD).

The calculations showed that the average GDP per capita growth rate (common ratio r) equalled 1.02956088 or $2.96 \%$ per year.

Next, one can extrapolate the GDP per capita of Latvia from 2001 to 1945 by using the mentioned geometric progression equation $\left(\mathrm{a}=1 / \mathrm{r}^{\wedge}((\mathrm{n}-1))\right)$ based on the CSB data (2001 prices).

The calculations showed that at a common ratio $\mathrm{r}=1.02956088$ and $\mathrm{l}=3174$ EUR, $\mathrm{a}=881 \mathrm{EUR}$.

Next, the GDP per capita of Latvia that represented military expenditures during communism is calculated; it is assumed that in case Latvia were an independent country, it would spend approximately $5 \%$ of its GDP on its military (author's estimate) (like during K.Ulmanis' rule before World War II) instead of 20$30 \%$ that was spent during the Soviet occupation, i.e. military expenditures on confrontation with the West are estimated at $15-25 \%$ of GDP. The calculations used an equation for calculation of a sum of geometric progression terms $(\mathrm{S})$ :

$$
S_{n}=\frac{a\left(r^{n}-1\right)}{r-1}
$$

The calculations showed that based on the Maddison project database data (at 2011 prices, based on purchasing power parities (PPPs) and the BalassaSamuelson effect), in the period 1945-1990 Latvia, not being an independent country, was forced to excessively spend on the USSR military in the range from USD 56553 (at a 15\%-point excess over 5\%, i.e. a total of $20 \%$ of GDP) to USD 94225 (at a 25\%-point excess over $5 \%$, i.e. a total of $30 \%$ of GDP) per capita. Given the average number of only native residents of Latvia in the mentioned period (around $1.6 \mathrm{mln}$.), the military expenditures were in the range from USD 90.5 to $150.8 \mathrm{bln}$.

However, based on the CSB data (2001 prices in EUR), the result ranged from EUR 12.1 to 20.2 bln. If adjusted for the GDP deflator available in the Eurostat database, the figure measured at 2011 prices is approximately $40 \%$ higher or in the range from EUR 17 to $28.3 \mathrm{bln}$

The calculation results are very diverse even if taking into account the USD/EUR rate assumed at 1.3. Based on the Maddison project database data, the figure ranges from EUR 69.6 to $116 \mathrm{bln}$. It is a threefold difference from the result based on the CSB data, which could be explained by the difference between PPPs-based data and current price data, the difference between both methodologies as well as the fact that the data on the GDP of the USSR, not to mention the military expenditures of the USSR, were a state secret. The results acquired could be considered to be approximate estimates, concluding that Latvia, not being a free country during communism, was forced to spend on confrontation with the West at least EUR 17 bln. (2011 prices) or approximately one GDP of that year (EUR 20.3 bln.).

\section{Conclusions}

1) Still, an inaccurate term for the economic system that existed during communism in the USSR as well as in most of the communist countries is used; this economic system has to be termed a mobilised (war) economy.

2) Among the former communist countries, only Yugoslavia had not introduced a mobilised economic system, thereby achieving a considerably higher standard of living during communism.

3) Amobilised(war) economy significantly lowers the standard of living, as a lot of resources are consumed by the military industry and related fields that do not contribute to prosperity, except for exports of weapons.

4) In a mobilised economy, goods (and services) are more valuable than money, which does not promote economic activity, unlike it is in a market economy. The function of money is partly performed by government orders (like in the army) and penalties for not obeying the orders.

5) Latvia, not being a free country during communism, was forced to spend on confrontation with the West at least EUR 17 bln. (2011 prices) or approximately one GDP of that year.

\section{References}

Central Statistical Bureau (CSB). (2019). IKG10_020. Gross domestic product from the production approach (thsd. euro). Retrieved October 10, 2019 from https://data1.csb.gov.lv/ 
pxweb/lv/ekfin/ekfin__ikp__IKP_ ikgad/ IKG10_020.px/table/tableViewLayout1/.

Central Statistical Bureau (CSB). (2019). ISG020. Population number and its change by statistical region, city, town and county. Retrieved October 10, 2019 from https://data1.csb.gov.lv/pxweb/lv/ iedz/iedz iedzskaits ikgad/ISG020.px/table/ tableViewLayout1/.

Colander, D.C. (1995). Economics. $2^{\text {nd }}$ ed. Chicago: Irwin. p. 860.

Encyclopaedia Britannica (2019). Collectivization. Retrieved October 7, 2019 from https://www. britannica.com/topic/collectivization.

Eurostat. (2020). Apparent Labour Productivity. Retrieved March 27, 2020 from http:// appsso.eurostat.ec.europa.eu/nui/ submitViewTableAction.do.

Latvijas rūpniecība pirms un pēc neatkarības atgūšanas (2015). 2013. gada 13. decembra konferences rakstu krājums. Latvijas Republikas Tieslietu ministrija (Industry of Latvia before and after Independence. 13 December 2013 conference proceedings. Ministry of Justice of the Republic of Latvia). Retrieved: https://www. barikadopedija.lv/images/9/9c/Rupnieciba.pdf. Access: 15.10.2019.

Linden, van der M. (2007). Western Marxism and the Soviet Union. A Survey of Critical Theories and Debates since 2017. Leiden: Brill. 379. p. Retrieved: https://books.google.lv/books?id=IMI $51 \times q k 5$ FC \&pg $=$ PA265\&lpg $=$ PA265\&dq $=\% 22$ mobilised + economy $\% 22 \&$ source $=$ bl\&ots $=u 9$ Yo QtqmVv\&sig=ACfU3U1TJVy-8wZhUyoPEWx pU_3rVgXfSA\&hl=en\&sa=X\&ved=2ahUKEwi gnLCdnKLiAhWMw8QBHRAbCnkQ6AEwCX oECAcQAQ\#v=onepage $\& q=\% 22$ mobilised $\% 20$ economy $\% 22 \& \mathrm{f}=$ false. Access: 15.10 .2019 .

Maddison Project Database (2018). Retrieved: https://www.rug.nl/ggdc/historicaldevelopment/ maddison/releases/maddison-projectdatabase-2018. Access: 15.10.2019.

Riekstins, J. (2015). Padomju impērijas koloniāāā politika un Latvijas kolonizācija 1940-1990 (Colonial Policy of the Soviet Empire and the Colonization of Latvia 1940-1990). Riga. p.200.

Rutkovska, A. (2011). Latvijas iekšzemes kopprodukts un nacionālais kopienākums (Gross Domestic Product and Gross National Product of Latvia). Retrieved: https://www.makroekonomika.lv/ latvijas-iekszemes-kopprodukts-un-nacionalaiskopienakums. Access: 08.10.2019.

Smulders, M. (1990). Who Owes Whom? Mutual Economic Accounts between Latvia and the USSR, 1940 - 1990. Riga. 38 p. Retrieved: http:// okupacijaszaudejumi.lv/content/files/Smulders1-Latv-PSRS\%20ekonom\%20sakari\%20un\%20 savst\%20norek.pdf. Access: 15.10.2019.

Tassava, C. (2008). The American Economy during World War II. EH.Net Encyclopedia, ed. Robert Whaples. Retrieved: http://eh.net/encyclopedia/ the-american-economy-during-world-war-ii/. Access: 15.11.2019.

World Bank (2002). Transition: The First Ten Years, Washington, D.C. Retrieved: http://documents.worldbank.org/curated/ en/319481468770972868/pdf/multi0page.pdf. Access: 07.10.2019.

Shaposhnikov, B. M. (1927). Mozg Armii. Tom 1 (The Brain of the Army. Volume 1). Retrieved: https://www.rulit.me/books/mozg-armii-tom-1read-3598-98.html. Access: 11.10.2019.

Slikov, V. (2001). Chto pogubilo sovetskiy soyuz? (What Ruined the Soviet Union?). Retrieved: http://svop.ru/wp-content/uploads/ 2018/10/VoennyVestnikMFIT_No8_CHTOPOGUBILO-USSR_RAZVEDKA-ŪSA.pdf. Access: 11.10.2019. 